\title{
Objective Approach to the Interpretation of Consciousness: Neurophysiological, Physical and Mathematical Discourses
}

\section{О6'єктивний підхід до трактування свідомості: нейрофізіологічний, фізичний і математичний дискурси}

Svitlana Kalishchuk Ph.D. in Psychology, Assistant Professor
Світлана Каліщук

кандидат психологічних наук, доцент

\author{
E-mail:klana@ukr.net \\ orcid.org/0000-0002-1749-7856 \\ Researcher ID: F-4321-2019
}

Kryvyi Rih Economic Institute of Kyiv National Economic University named after Vadym Hetman, Kryvyi Rih, Ukraine 64 , Post avenue, Krivyi Rih, Ukraine, Dniprovskyi region, 50000
Криворізький економічний інститут ДВНЗ «Київський національний еконолічний університет ілені Вадила Гетьмана», л. Кривий Ріг, Україна пр. Поштовий, 64, м. Кривий Ріг, Дніпровська обл., 50000

Original manuscript received March 18, 2019

Revised manuscript accepted April 16, 2019

\section{ABSTRACT}

In the article basic researches of objective cognition of consciousness revealing various aspects of formation of skill of distinction and radiation of consciousness are described. The complementary approaches of the natural scientific discourse of consciousness research are analyzed, namely neuro- 
physiological ones, which raise the question of biological fundamentals of the interlevel phenomenon of consciousness and determine the physiological basis structural-functional suilding of consciousness; quantum-mechanical, based on the practice of experimental research of quantum reality and explaining the phenomenon of "consciousness»; and the system-wide, which holistically and logically-conceptually allows to simulate the system space of consciousness and acts as the operating paradigm of research. Meaningful and structural formal-logical and functional features of consciousness are investigated by methods of theoretical modeling and reconstruction. The essence of classical and modern neurophysiological theories of consciousness is revealed. Neuropsychological theories can be considered as a structural-functional paradigm, which is the function of specific neural networks, cognitive processes, synchronization of neural circuits and creation of new neural pathways in the background preserving the function of old ones, collapsing and deploying multiple forms of information, merging experiences of the whole experience. The principles of quantum mechanics act as an explanatory paradigm, which interprets the phenomenon of altered states of consciousness and the content structure of consciousness, the units of which are the meanings that intention aspire correlate the conscious quality with the integral picture of the world due to the existence of a semantic field. The general theory of systems provides creation of system "semantic territory" of consciousness of the personality; the finding of bifurcation points in which the fullest possible set of potential growth possibilities of the system is shown; definition of reinforcing and balancing feedback loops; desired state of the system; type of attractors; the potential of self-manifestation and self-liberation in personal activity and building a unique own reality through continuous exchange with the outside world.

Key words: consciousness, neurophysiology of consciousness, quantum mechanics, general theory of systems, structural-functional paradigm, explanatory paradigm, operating paradigm.

\section{Вступ}

Питання про природу свідомості («Що являє собою свідомість?») і про її характерні особливості («Як здійснюється випромінювання свідомості?», «Яким чином відбувається внутрішне дистанціювання від наявної дійсності?», «Як саме виникає досвід розрізнення?») мають велику кількість відповідей у різних підходах і парадигмальних 
рамках. Це проявляє актуальність дослідницького пошуку, який спрямовується науковцями як у побудову онтологічних філософських і психологічних моделей свідомості (Kalishchuk, 2018; Роменец, 2003; Фурман, 2017), так і в широкий простір міждисциплінарних спроб (Иванов, 2008; Менский 2011). Кількість теорій свідомості - як індуктивних, так і дедуктивних - зростає, але це не унеможливлює розуміння й знаходження способів вирішення проблеми, якщо знайти засади, які на певному рівні порядку концептуально оформлюють досліджуваний феномен.

Зауважимо, що між суб'єктивною (гуманітарні науки про внутрішній світ людини) й об'єктивною (природничі науки про матеріальний світ) галузями наукового пізнання існує важливий зв’ язок. Тому кожна з цих галузей знання виявляється логічно незамкненою, якщо інша виключена з наукового розгляду. Загально-теоретичні філософські погляди та спроби концептуалізації свідомості в межах психологічних теорій неможливо розглядати окремо від пояснення свідомості у природничо-науковому дискурсі.

Мета статті - проаналізувати базові підходи об'єктивного трактування свідомості, що розкривають різні аспекти формування досвіду розрізнення та випромінювання свідомості.

\section{Завдання статті}

1) Розглянути базові теорії природничо-наукового дискурсу дослідження свідомості, а саме:

- нейрофізіологічні, які порушують питання про біологічні засади міжрівневого феномену свідомості та визначають фізіологічні основи структурно-функціональної будови свідомості;

- квантово-механічні, що спираються на практику експериментального дослідження квантової реальності та пояснюють феномен «квантова свідомість»;

- загально-системні, які дають змогу цілісно та логіко-концептуально змоделювати системний простір 
свідомості й виступають операційною парадигмою її дослідження.

2) Простежити загальний вплив дослідження свідомості в природничо-науковому дискурсі на пошук відповіді на питання про природу та зміст свідомості.

\section{Методи та методики дослідження}

Процедура теоретико-методологічного дослідження забезпечує досягнення змістового і структурно-організаційного результатів аналізу феномену свідомості та складається з методу моделювання - відтворення сутнісних ознак свідомості й методу реконструювання - змістовного та структурного визначення внутрішніх, формально-логічних і функціональних ознак свідомості.

\section{Результати та дискусії}

Вихідним кроком об'єктивного трактування свідомості виступають нейрофізіологічні засади, що розглядають свідомість як механізм контролю і довільної регуляції поведінки й діяльності. Згідно Л. М. Веккера, парадоксальність психічного полягає у тому, що його основні характеристики формулюються в термінах якостей зовнішньої реальності, яку психічне відображає (Веккер, 1998), a саме: «адекватне відображення змін зовнішнього і внутрішнього середовища» та «забезпечення адаптації організму до них». А відповідь на питання: «Що являють собою виконавчі структури та нейрофізіологічні механізми свідомості?» міститься в численних структурних теоріях нейронних мереж і функціональних теоріях дослідження когнітивних функцій та ієрархічно організованих мозкових систем. До впливових теорій нейрофізіологічного пояснення свідомості відносять:

1. Теорію «світлої плями» І. П. Павлова, згідно якої свідомість розглядається як діяльність збудженої зони «творчої ділянки», що переміщується на темному тлі по корі великих півкуль. Це зона локальної активації мозко- 
вих структур, у якій легко створюються умовні рефлекси та диференціювання. На відміну від «світлої плями», інші зони належать до несвідомої діяльності та відповідають за підтримання вже створених рефлексів (Данилова, 1999).

2. «Прожекторну теорію свідомості» Ф. Кріка, згідно якої умовою виникнення потоку виступає збудження одного з таламічних центрів, що забезпечує створення в корі зони підвищеної збудливості тривалістю близько 100 мс. Зона найсильнішої імпульсації створює певний центр уваги, а постійне переміщення потоку збудження забезпечує об'єднання імпульсів збудження у єдину систему з частотою гамма-діапазону (35-70 Гц). У системі в сумісній діяльності об’єднуються нейронні ансамблі в різних зонах кори великих півкуль. На думку Ф. Кріка, така інтеграція забезпечує виконання вищих психічних функцій, а нейронні процеси, що перебувають у зоні уваги «прожектора», визначають зміст свідомості у певний момент часу (Данилова, 1999).

3. Теорію «повторного входу збудження» Д. Едельмана. Автор запропонував схему й описав складові первинного і вторинного потоків інформації, що акумулюють один цикл, або повторювану фазу активності свідомості. Сенсорна інформація від зовнішнього і внутрішнього середовища

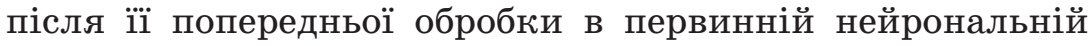
групі повторно входить до неї, повертаючись після додаткової обробки, здійсненої в інших групах клітин. Отже, за Д. Едельманом, головною умовою усвідомлення виступає зв'язок груп нейронів кори великих півкуль із мультимодальними асоціативними структурами, що накопичують минулий досвід. Це дає змогу зіставляти існуючі в пам'яті відомості зі змінами, що відбулися впродовж одного циклу обробки інформації. Проходження одного циклу збудження здійснюється впродовж 100-150 мс. Такі повторювані цикли створюють нейрофізіологічну «канву» свідомості (Эдельман, 1981). 
4. Теорію «інформаційного синтезу» О. М. Іваницького, у якій розкривається роль об’єднання двошарової інформації (сенсорні властивості стимулу та семантичні властивості стимулу), яка приходить із пам'яті. Синтез двох видів інформації забезпечує виникнення усвідомлення. Цей процес здійснюється з періодом квантування у 100-150 мс. Послідовність процесу оцінки й усвідомлення сприйняття стимулу має такий вигляд: сенсорний стимул $\rightarrow$ збудження нейронів проекційної кори $\rightarrow$ асоціативна кора $\rightarrow$ структури лімбіко-гіпокампального комплексу $\rightarrow$ підкіркові центри емоцій і мотивацій $\rightarrow$ проекційні відділи кори $\rightarrow$ лобна кора. Провідною ланкою виступає синтез інформації на нейронах проекційних відділів кори великих півкуль. Головне положення теорії «інформаційного синтезу» полягає у зв'язку сенсорного відчуття із суб'єктивними показниками сприйняття стимулу (Іваницький, 2005).

5. Теорію свідомості Д. Еклза, що базується на особливій функції дендритів пірамідальних клітин кори великих півкуль збиратися в дендритний пучок ( «дендрон») на рівні IV шару кори і досягати I шару. Дендрон із великою кількістю синапсів і терміналів аксонів, згідно Д. Еклза, є носієм свідомості в силу притаманної йому функції генерувати «психони». «Психон»- це суб’єктивний феномен, що відповідає окремому дендрону і виступає одиницею локального відчуття та виявляється за допомогою інтроспективних методів. Зв'язки між «психонами» та дендронами $\epsilon$, за думкою автора, нейрофізіологічним проявом свідомості. Велика кількість усіх можливих «психонів» забезпечує неймовірну різноманітність суб'єктивних явищ особистості. Крім того, Д. Еклз описує процес «викиду квадра медіатора», розуміючи цю дію як існуюче нематеріальне джерело свідомості, що впливає на дендрони. Авторові вдається пояснити механізм здійснення поведінкових актів і прояв людиною «свободи волі» через керування імовірністю вивільнення квантів медіатора (Хант, 2004). 
6. Голографічну теорію К. Прибрама, що базується на холономних принципах і пояснюе механізми та процес згортання множинних форм інформації в різних зонах кори великих півкуль та її розгортання вже як свідомості. Згідно К. Прибрама, зовнішня інформація розподіляється по нейронній системі та створює стійкі «візерунки» синаптичних мікроструктур у тих ділянках мозку, де сприймаються та згруповуються вхідні впливи. Тобто, процес згортання сенсорних сигналів породжує множинні та просторово розповсюджені вузли взаємного підсилення й ослаблення (Прибрам, 1975). Тому кожен момент усвідомлення зливається у досвід пережитого цілого, у якому важко диференціювати різні модальності сприйняття, особливості почуття, спрямованість і константність думок, ознаки дихання, симптоми та реакції тіла. Підкреслюючи вірність холономного підходу, Г. Глобас указує на наявність у нервовій системі кожного біологічного виду всіх можливих «перцептуальних конфігурацій» оточуючого середовища. Така інформація має латентну форму (Хант, 2004). Спираючись на дослідження О’ Кіфа, К. Прибрам наголошує, що зовнішнє середовище багато разів представлено в гіпокампі подібно голограмі. Крім того, один і той самий нейрон гіпокампа може брати участь у створенні різних картин світу, а репрезентація будь-якої ділянки середовища залежить від активності великої групи нейронів і повторюється одночасно на різних нейронах гіпокампа. Гіпокампальний тета-ритм розглядається К. Прибрамом як механізм сканування інформації. Акумуляція різних інформаційних аспектів, кодування та декодування інформації в гіпокампі, де актуалізується з довгострокової пам'яті надлишкова інформація, забезпечує побудову суб'єктивної картини світу, що прагне до точності й адекватності.

7. Ієрархічну модель гештальту С. М. Соколова, у якій сенсорний стимул збуджує високочастотні коливання певної частоти, що позначаються як пейсмекерна активність таламуса (Соколов, 2006). Нейронне розрізнення сенсор- 
них стимулів здійснюється в ієрархічній піраміді, вершиною якої виступає гностична одиниця. Гностичні одиниці спеціалізуються і реагують у кожній ієрархічній піраміді винятково на специфічний комплекс сенсорних подразників. Є. М. Соколов припускає, що активація такої піраміди неспецифічними високочастотними ритмами таламічних нейронів одночасно зі специфічним сенсорним сигналом веде до усвідомлення. Отже, активована гештальт-піраміда ієрархічно організованих нейронів становить основу будь-якого свідомого акту. Сам свідомий акт включає, на думку Є. М. Соколова, три рівні суб’єктивного відображення: перцептивний, мнемічний і семантичний. Перцептивний виникає за умови активації гештальт-піраміди і призводить до формування перцептивного образу. Мнемічний забезпечує порівняння сенсорного образу з образами довготривалої пам'яті. Семантичний починається з дії нейронів пам'яті, що здійснюють категоризацію сигналів. Свідомість розглядається автором як результат дії паралельно діючих незалежних нейронних модулів, що створюють дві когнітивні системи: вентральну, яка відповідає за зміст сигналу, та дорзальну, що складає просторове уявлення.

8. Теорію фрунціональних систем як виконавчих структур свідомості, що сприяють отриманню життєво важливих для організму пристосувальних результатів (Анохин, 1975). П. К. Анохіним виокремлено такі основні принципи існування функціональних систем: взаємоспівдії для отримання сфокусованого корисного результату; динамічності як досягнення запрограмованого корисного результату; ієрархічності, що відображає багаторівневість і наявність системи вищого порядку; саморегуляції за допомогою механізму зворотної аферентації й апарату акцептора результатів дії для досягнення запрограмованого результату; мінімізації - введення до структури функціональної системи лише тих елементів, що необхідні для отримання кінцевого результату. Отже, теорія функціональних систем П. К. Анохіна дає змогу пояснити психіч- 
ний феномен свідомості, спираючись на корисний пристосувальний ефект, як антиципацію майбутнього.

9. Системно-еволюційну теорію В. Б. Швиркова, згідно якої мозок несе в собі велику кількість «мовчазних" клітин, а кількість активних клітин збільшується за умови научування. Научування призводить до залучення нових нейронів, а не переучування старих. В. Б Швирков розглядає поведінковий акт як компоненту послідовних поведінкових актів, заданих процесом досягнення та можливістю оцінки результату попереднього поведінкового акту (Швырков, 2006). Це положення являє собою психофізіологічну відповідь на питання про можливість трансформації та переходу з одного рівня функціонування особистості на інший.

10. Теорію глобальних нейронних інформаційних просторів Зॄ.-П. Шанже, що виступає розвитком теорії глобального робочого простору Б. Баарса. Згідно авторів, те, що індивід відчуває як свідомий доступ до інформації - $€$ відбір, посилення і трансляція певної кількості інформації в зонах кори великих півкуль. Нейронна мережа включає в себе: пірамідальні нейрони лобної та префронтальної часток кори, скроневих часток, премоторну кору (Шанже, 1999). Автор підкреслює, що зв'язки між елементами мозку в силу явищ конвергенції та дивергенції організовані у деревоподібне розгалуження нервових клітин, яке являє собою чималу мережу і вказує, що координації нейронів сприяє научування, тобто відбір миттєвих «попередніх» образів із тих, що генеруються нейронною мережею. Аналізуючи поняття «свідомість», ЗЖ.-П. Шанже визначає, що «усвідомлююче середовище» являє собою нейронний інформаційний простір мозку, який просторово знаходиться між організмом і зовнішнім світом з усіма соціальними та фізичними зв'язками і слугує полем для оцінки намірів, цілей, програм дій, які постійно співвідносяться з поточною взаємодією зі сприйняттям зовнішнього світу, з «образом-Я», з подіями особистісної історії, зі спогадами 
про минулі відчуття, з емоційними характеристиками, із соматичними маркерами, з інтерналізованими соціальними нормами. Згідно Жீ.-П. Шанже, лобні долі кори великих півкуль разом із лімбічною системою беруть участь в «усвідомленому» прийнятті рішення, активуючи почуття емпатії та симпатії і знижуючи агресію; нейрони ретикулярної формації відповідають за увагу і пильність, їх перезбудження може викликати роздратування. Процедурно процес усвідомлення Ж⿱乛龰-П. Шанже описує за допомогою таких процесів:

- переміщення психічних структур між тими зонами мозку, що відповідають за довгострокову та короткострокову пам'ять;

- вплив критеріїв новизни інформації;

- прояв реакції на виниклі когнітивні антиципації;

- організаційні функції та роль «оператора» при сприйнятті інформації;

- інтерналізація нових структур у церебральній мережі;

- гнучкість зв'язків, яка забезпечує можливість випадкових дій.

Отже, згідно ЗЖ.-П. Шанже, нейронний інформаційний простір дає змогу здійснювати внутрішній розвиток психічних структур і складати змістовну будову свідомості.

Іншою гранню призми об’єктивного пізнання свідомості виступає квантова механіка як спроба дати відповідь на питання про особливості суб'єктивної побудови реального виміру дійсності. Концептуальні положення теорії вимірів спираються на правило, згідно якого спостереження порушує суперпозицію об'єкта і змушує його прийняти один зі своїх станів у хвильовій функції. Наслідком виступають такі часткові узагальнення:

1. Квантовий об'єкт у кожного дослідника проявляє свої специфічні стани відповідно до принципу невизначеності В. Гейзенберга. Автор стверджує, що спостереження за квантовою речовиною впливає на траєкторію цієї речо- 
вини. А тому знання дійсної природи квантового об’єкта, зокрема, його швидкісних і просторових властивостей, $\epsilon$ неможливим (Гейзенберг, 2015).

2. Результатом взаємодії квантової системи, обладнання та спостерігача виступає суперпозиційний стан. Згідно багатосвітової інтерпретації, стани світу можуть існувати як співіснуючі стани. Для будь-якого класичного стану квантової системи її майбутній стан представляється як набір співіснуючих станів у суперпозиції, як суми можливого набору векторів станів. Цей посил базується на понятті «логічні структури» теорії Х. Еверетта про об'єктивно співіснуючі всі можливі альтернативні сценарії світів та індивідуального життя в них (Everett, 2007).

3. Спроможність свідомості будувати реальний i альтернативний сценарії у послідовні моменти часу. М. Б. Менський визначає свідомість як розрізнення та вибір класичних альтернативних реальностей, які у своїй сукупності формують квантову реальність (Менский, 2011). Механізм здійснення розрізнення полягає у тому, що свідомість кожен певний момент часу розрізнює альтернативні світи таким чином, що суб'єктивно виникає ілюзія існування тільки одного сприйнятого світу. Отже, з плином часу виникає альтернативний сценарій як прояв певної можливості з ланцюга альтернативних світів у послідовні моменти часу.

Отже, багатосвітова інтерпретація Х. Еверетта та пояснення реальності як «мультиверса», виступають теоретичною засадою поєднання свідомості та квантової механіки. Д. Бом побудував на цій засаді повну модель фізичної реальності та центральної нервової системи (Бом, 1967). Змістовно модель Д. Бома Ірунтується на існуванні сукупного «латентного порядку», який уміщує одночасно згорнуті окремі події світу. Кожна частина такого сукупного «латентного порядку» може бути розгорнутою на основі організуючих принципів цілого. Крім того, якщо базуватися на визначенні, що свідомість - це розрізнення альтер- 
натив, то логічно вважати, що за умови виключення свідомості, розподіл альтернатив зникає, а залишається існувати одночасний прояв багатоваріативності реальності. Це означає, що відбиття ( «сприймання») всіх альтернативних світів одночасно стає доступним. Прикладами виступають різноманітні змінені стани свідомості, а саме: сон, транс, гіпноз, регресивний гіпноз, медитація, холотропний стан тощо. М. Б. Менський робить висновок, що мозок не створює свідомість, а виступає її інструментом.

Індивідуальну селекцію альтернатив, що безпосередньо пов'язана з чуттєвим сприйняттям, виокремлює як головне положення пояснення квантової реальності С. М. Іванов (Иванов, 2008). Свідомість, згідно автора, вибирає саме те, що ми чуттєво сприймаємо, а тому вибір альтернативи та чуттєве сприйняття збігаються. Несприйняті альтернативні реальності залишаються у складі суперпозиції як потенціальна можливість. Абсолютний за часом вектор станів світу являє собою, за С. М. Івановим, «квантовий кристал», структуру, в якій первісно записані всі можливі актуалізації світу. Автор доводить, що свідомість вибиpaє і сприймає одну з альтернатив, не здійснюючи ніякого впливу на фізичну реальність. Мозок, згідно Є. М. Іванова, виступає для свідомості об'єктом сприйняття, через який свідомість сприймає і весь світ. Якщо мозок знаходиться у стані суперпозиції, компоненти якої відповідають різним сприйняттям, то свідомість сприймає лише одну з цих компонент, ігноруючи інші. Саме це забезпечує одиничність та однозначність сприйняття й цілісність суб'єкта. Процес актуалізації реальності С. М. Іванов описує як «хвилю збудження», що розповсюджується всередині «квантового кристала» упродовж часової осі. Рух по часовій осі являє собою сукупність точок, кожна з яких - це окрема індивідуальна свідомість. «Точки» переміщуються за певними взаємоузгодженими траєкторіями та не мають зворотного впливу на «квантовий кристал». Спостерігач має можливість відрізняти лише одну компоненту суперпозиції. Але 
інші компоненти теж пізнавані, ними виступають думки та смисли. Отже, С. М. Іванов уводить поняття смислу як потенційного змісту свідомості, який не має просторових і часових характеристик, але несе в собі інтенцію співвіднесення з інтегральною картиною світу того предмета, який усвідомлюється. Автор розглядає три компоненти функції свідомості: функцію усвідомлення почуттєвого сприйняття, функцію розуміння-осмислення і функцію усвідомлення прийнятого рішення. Головними з цих функцій виступають: усвідомлення сприйнятого $\left(\mathrm{F}_{1}\right)$ та усвідомлення прийнятого рішення $\left(\mathrm{F}_{2}\right)$. Усвідомлення сприйнятого здійснює селекцію квантових станів «сенсоріуму», а усвідомлення прийнятого рішення здійснює селекцію квантових станів «командного центру». Схематично функція свідомості, згідно автора, може бути описана формулою, в силу того, що взаємодія «сенсоріуму» і «командного центру» породжує суперпозицію, яка містить в собі всі можливі комбінації результатів сприйняття станів зовнішнього світу і сприйняття рішень, що приймаються «командним центром» :

$$
\begin{gathered}
\mathrm{c}_{1}\left|\Phi_{1}>\right| \mathrm{S}_{1}>\left|\mathrm{R}_{1}>+\mathrm{c}_{2}\right| \Phi_{1}>\left|\mathrm{S}_{1}>\right| \mathrm{R}_{2}>+\mathrm{c}_{3}\left|\Phi_{2}>\right| \mathrm{S}_{2}>\mid \mathrm{R}_{1}>+ \\
+\mathrm{c}_{4}\left|\Phi_{2}>\right| \mathrm{S}_{2}>\mid \mathrm{R}_{2}>,
\end{gathered}
$$

де: $\Phi_{1}$ і $\Phi_{2}-$ альтернативні стани світу до взаємодії 3 мозком;

$\mathrm{S}_{1}$ i $\mathrm{S}_{2}$ - альтернативні стани «сенсоріуму»;

$\mathrm{R}_{1} \mathrm{i} \mathrm{R}_{2}$ - альтернативні стани «командного центру» .

Функція усвідомлення сприйнятого $\mathrm{F}_{1}$ - маркує, з урахуванням значень коефіцієнтів $\mathrm{c}_{1}$ i $\mathrm{c}_{2}$, одну 3 компонент суперпозиції. Функція усвідомлення прийнятого рішення $\mathrm{F}_{2}$ - актуалізує одну з чотирьох компонент $\mathrm{c}_{1}, \mathrm{c}_{2}, \mathrm{c}_{3} \mathrm{i} \mathrm{c}_{4}$, роблячи її почуттєво сприйманою. С. М. Іванов підкреслює, що $\mathrm{F}_{2}$ здійснює вибір актуалізованої компоненти раціонально, враховуючи можливі наслідки вибору, співвідносить суперпозицію зі станом смислового поля, виходячи при цьому за межі можливостей фізичного мозку. Саме тому автор визначає $\mathrm{F}_{2}$ функцією свідомості. Отже, на думку 
Є. М. Іванова, свідомість, сприймаючи фізичну реальність, створює ілюзію психофізичної взаємодії, тоді як дія свідомості зводиться лише до вибору й актуалізації тих компонент «квантового кристала», у яких ця дія вже здійснена. Свідомість керує кожним процесом селекції альтернатив за умови, що ці альтернативи проявляються на макрорівні у вигляді альтернативних дій складної системи, здатної сприймати оточуючий світ і діяти доцільно. Свідомість не може впливати на світ, але за допомогою селекції альтернатив цілеспрямовано впливає на індивідуальне сприйняття світу. Процес усвідомлення, за Є. М. Івановим, можна уявити у вигляді «блукання» точки усвідомлення всередині «квантового кристала» у пошуках тієї частини, у якій це сприйняття буде реалізоване, в силу того, що ця частина містить в собі потенції для трансцендентного.

Загальна теорія систем розглядається нами як третя необхідна грань пізнання свідомості в об’єктивному дискурсі. Первісно, у теорії систем знаходить своє обгрунтування ідея Р. Сперрі про якості свідомості, що виникають винятково як системні «організаційні процеси більш високого порядку» (Хант, 204: 96). Аналіз феномену «свідомості» у дослідницькому просторі системної парадигми дає змогу визначити такі основні атрибути свідомості як системи:

1. Свідомість - це відкрита система, яка має, за висловом Л. фон Берталанфі, «плинну рівновагу», в силу того, що поєднує стійкість структури з гнучкістю змін. У точках біфуркації стани вищого порядку виникають спонтанно, але базуються на інтенційних можливостях системи. Це момент перетворення хаосу в порядок, енергії кризи у відкриття смислу. Ф. Капра визначає такі ключові ознаки системи: патерн (конфігурація взаємовідносин, що встановлює суттєві характеристики системи); структура (фізичне втілення патерну) та життєвий процес (діяльність, спрямована на безперервне втілення патерну) (Капра, 2002). Взаємозв'язок між розумом і мозком являє собою 
взаємозв'язок між процесом і структурою. Свідомість як когнітивна система, що постійно навчається, передбачає наявність патернів взаємовідносин як «автопоезної мережi» (Varela, 1995).

2. Свідомість як система дозволяє «усвідомлювати, що ми усвідомлюємо» (Капра, 2002). Свідомість є проявом емерджентних властивостей системи, що вперше виникають у роботі системи як первинної цілісності та включають у себе зовнішній і внутрішній світ, усі форми психічної діяльності й тілесну форму і не зводяться до якостей їі складових елементів, а також зумовлюють головні їi характеристики. Тобто, свідомість має свої власні холістичні властивості, ознаки та функції, які не тільки не зводяться до певної нервової підструктури, але й управляють своїми нервовими складовими нижчого порядку (Хант, 2004). Нові системні властивості з' являються з організуючих відносин між елементами, тобто з конфігурації впорядкованих взаємовідносин між первинними елементами, а саме: між увагою, сприйняттям, мисленням, мовою, рефлексією, емоційними станами, пам'яттю тощо. Емерджентними ознаками свідомості виступають: цілісність суб'єкта, збагнення глибинної суті у «переживанні-проживанні», «випромінювання та проникаюча активність суб’єкта» (Бескова, 2001), фрормування ментального досвіду «Я», «перцептуальне з'єднання» «тут» $\mathrm{i}$ «там» (Гибсон, 1988), стан «Я є» (Almaas, 1996) та інші.

3. Аналіз системи, який з'ясовує її окремі складові, знищує емерджентні властивості системи та позбавляє можливості зрозуміти зміст, функції та особливості системи. Тому визначення свідомості як функції мозку хоча й спирається на закони руху матерії, з якої складається мозок, і на опис функцій виконання обчислювальних операцій за допомогою блоків уведення і виводу інформації, петель зворотного зв' язку, але не допомагає зрозуміти сутність свідомості. Нервові мережі збирають, фокусують й організовують чутливість і сприйняття, але не створюють 
ї. Тому різноманітні структурні концептуалізації площинної будови свідомості не дають змоги визначити загальноутворюючу засаду для пояснення функціонального та сутнісного прояву природи свідомості.

4. Розуміння свідомості як «динамічної якості певних патернів нервової організації більш високого порядку» можливе тільки за умови її спостереження в дії. Об’єкти, що сприймаються свідомістю, створюються через дію. Ф. Варела підкреслює, що дія свідомості полягає у безперервному «патерні пошуку» зовнішніх і внутрішніх підстав незалежного та заздалегідь визначеного світу за допомогою безперервного створення мовної мережі, відкриття значення як патерну взаємовідносин між мовними розрізненнями та побудови «семантичної території» особистості (Капра, 2002).

5. За I. Пригожиним, основними механізмами, що забезпечують динаміку системи свідомості, виступають регуляція та саморегуляція «дисипативних (розсіювальних) структур», які не тільки підтримують себе в сталому стані нерівноваги, але й розвиваються, використовуючи зовнішню або внутрішню енергію (наприклад, при переживанні кризи, відкритті смислу як семантичного інваріанту, з якого складається будова «картини світу», або при переживанні парадоксальності смислу) для власної трансформації та спіральної динаміки, а саме: збільшення своєї складності та переходу на вищу форму організації й порядку. Наявність «дисипативних структур» пояснює парадоксальне сполучення змін і стабільності свідомості як системи. Дисипативні структури підтримують себе у сталому стані, який потенційно готовий до зрушення, а тому вже не виступає постійною рівновагою. За I. Пригожиним, дисипативні структури - це «острівці порядку в морі безпорядку», які підтримують і навіть підвищують свій порядок за рахунок збільшення безладу оточуючого середовища (Капра, 2002). Велика мережа процесів метаболізму підтримує систему в далекому від рівноваги стані й, через 
петлі зворотного зв'язку, викликає біфуркації, забезпечуючи тим самим розвиток і еволюцію. Завдяки дисипативним структурам підтримується єдина загальна структура, незважаючи на неперервний потік і зміну компонентів системи. Це задає напрямок еволюціонування особистості.

6. Згідно теорії «автопоезу», свідомість взаємодіє 3 оточуючим середовищем через структурне сполучення, а саме через повторювальні взаємодії, кожна з яких запускає структурні зміни в системі (Varela, 1995). Автопоезна система переживає неперервні структурні зміни, зберігаючи одночасно свій патерн. Свідомість не тільки визначає структурні зміни, вона здатна визначати, які саме зовнішні сигнали ініціюють їх. Структурні зміни в свідомості це акти пізнання. Пізнання трактується як «втілена дія», за думкою Ф. Варела, в силу того, що в усіх когнітивних процесах сприймання і дія не відокремлені (Varela, 1995). Система свідомості протистоїть змінам, завжди прагне до сталого стану з мінімальною ентропією та інтенційно спрямована до сталої рівноваги. Разом із тим, абсолютний стан рівноваги означає смерть, тому система одночасно мінімізує, але не виключає свій плин до нового стану. Прикладом повторювальних феноменів первісно адаптивної фіксації свідомості можуть виступати система психологічних захистів особистості, «улюблені емоції», переконання «супер-Его», автоматизм сприйняття та розуміння тощо.

7. Поводження системи залежить від того, як пов'язані між собою її елементи, тобто від модальності, якості й іманентно заданих властивостей існуючих зв'язків між ними, а не від самих елементів. Тому формування образу «картини світу» особистості як проекції свідомості та їі розвиток залежить не від окремих елементів «картини світу», які $\epsilon$ відносно сталими по суті своєї власної феноменології. Зміни, як перехід на вищий рівень порядку, є проявом динаміки або кризової зміни зв'язків між об'єктами. Здійснюється це в точці біфуркації, в потенціальному наборі всіх можливих спрямувань системи. Тому динамічна склад- 
ність системи підсилюється існуванням потенційно великої кількості зв'язків між її елементами в силу того, що кожен елемент може перебувати в декількох різноманітних станах. Прикладом може слугувати альтернативність емоційних і поведінкових патернів особистості як множинності реакцій на сукупність зв'язків усередині системи, різноманітність пізнавальних контурів, мультимодальність простору особистості та пошук амодального смислу як розширення поля усвідомлення. А також, наприклад, взаємна зміна та чергування процесів «злиття - сепарації» на кожному потенційно необхідному етапі реконструкції викривленої «картини світу» особистості й усвідомлення необхідності її динаміки.

8. У системах існує «принцип важеля», згідно якого найменший вплив може стати причиною значних змін. У точці біфуркації «дисипативна структура» може або зруйнуватися, або прорватися до одного з декілька нових станів порядку. Спрямованість змін залежить від того, яким шляхом система досягла точки нестійкості. У точці біфуркації структура проявляє виняткову чуттєвість до мінімальних флуктуацій в оточуючому середовищі. Це, за словами I. Пригожина, є проявом «порядку через флуктуацію» (Капра, 2002: 209). Смислова будова свідомості забезпечує прояв «принципу важеля» через відкриття парадоксального смислу. Ефект змін потребує часу, в силу того, що у змінах задіяний увесь контур зворотного зв'язку. Зв'язки між елементами системи формують петлі зворотного зв'язку. Стрибок на новий рівень організації є наслідком флуктуацій, посилених петлями додатного зворотного зв'язку. Такий підсилюючий зворотний зв'язок виступає джерелом нового порядку і складності в системі. Прикладом може слугувати траєкторія виходу з панічних атак або рівні пробудження за К. Грейвзом, які різняться залежно від: сприймання зовнішнього світу; характерних методів реагування на проблеми; ступеня усвідомлення власного прагнення. 
9. Система має схильність повертати частину вихідної інформації на вхід і тим самим впливає на її функціонування. Контур зворотного зв'язку між елементами системи може бути підсилюючим, що призводить до експоненціального зростання, й урівноважуючим, що протидіє змінам системи. Це проявляється в силу того, що система завжди має мету, а саме: бажаний стан, у якому система перебуває в рівновазі. Визначення меж системи та якісної характеристики атракторів, її точок тяжіння, тих стабільних станів, до яких тяжіє система - виступають критеріями зростання системи. Причина дестабілізації системи знаходиться в унікальних атрибутах елементів системи, iii структурі та взаємовідношеннях внутрішніх чинників або станів, що зумовлюють постійно відтворюваний патерн явища. Тому свідомість має як властивість прагнути до гомеостазу і захищати звичну, напрацьовану «картину світу», так і властивість до експоненціального зростання й ускладнення сталої картини.

\section{Висновки}

Описані концептуальні підходи дають змогу побудувати пошуковий простір феномену «свідомість», грунтуючись на постулатах нейрофізіології, квантової механіки та загальної теорії систем. Проведений розбір з опорою на об'єктивний рівень аналізу складного суб'єктивного феномену дає відповіді на питання, як здійснюється досвід розрізнення альтернатив реальності, як співвідноситься старий і новий досвід, як забезпечується унікальність індивідуальної картини світу та різноманітність суб'єктивних явищ особистості. Так, нейропсихологічні теорії можна розглядати як структурно-функціональну парадигму, що характеризує функції та рамки специфічних нейронних мереж як складну структуру інформаційного поля та як прояв конкретного когнітивного процесу і синхронізації різноманітних нейронних ланцюгів, залучення нових нейронних шляхів на тлі збереження функції старих, згор- 
тання та розгортання множинних форм інформації й як прояв злиття досвіду пережитого цілого. Положення квантової механіки можуть виступати як пояснювальна парадигма, в рамках якої накопичується об'єктивна аргументація в пошуку відповідей на питання: «Як з'являється у процесі спостереження суб’єктивна картина світу? $\mathrm{i}$ «Як здійснюється перетворення об’єктивно існуючого стану світу в суб’єктивно сприйняту картину світу?», пояснюється феномен змінених станів свідомості та змістова будова свідомості, одиницями якої виступають смисли, що не мають просторових і часових характеристик, але інтенційно прагнуть співвідносити усвідомлену якість з інтегральною картиною світу завдяки існуванню смислового поля. Основні атрибути свідомості як системи дають можливість розглядати загальну теорію систем як операційну парадигму дослідження свідомості, що забезпечує побудову унікальної власної реальності шляхом безперервного обміну із зовнішнім світом.

Отже, огляд досліджуваних конструктів пізнання свідомості в об'єктивному дискурсі дав змогу розкрити фізіологічні основи структурно-функціональної будови, змісту і дії свідомості й «усвідомлюючого середовища» як нейронного інформаційного простору мозку; пояснити інтенційну властивість картини світу до змін і розкласти на операційні дії процес побудови архітектоніки смислів особистості; відповісти на питання, як здійснюється зростання особистості та що може утруднювати психотерапевтичну дію напрацювання нового досвіду усвідомлення себе й оточуючого світу.

\section{Література}

Бескова И. А. Эволюция и сознание: когнитивно-символический анализ. Москва : ИФ РАН, 2001.179 с.

Бом Д. Специальная теория относительности. Москва : Мир, 1967. 256 с. Веккер Л. М. Психика и реальность: Единая теория психических процессов. Москва : Смысл, 1998. 605 с. 
Гейзенберг В. Принцип неопределенности. Москва : Агостини, 2015. $234 \mathrm{c}$.

Гибсон Дж. Экологический подход к зрительному восприятию. Москва : Прогресс, 1988. 464 с.

Данилова Н. Н. Психофизиология. Москва : Аспект Пресс, 1999. 373 с. Іваницький О. М. Свідомість і мозок. У світі науки. 2005. № 11. С. 9-14.

Иванов А. В. Мир сознания. Барнаул : Алтайский дом печати, 2008. $432 \mathrm{c}$.

Капра Ф. Паутина жизни. София : Гелиос, 2002. 335 с.

Менский М. Б. Сознание и квантовая механика: Зћизнь в параллельных мирах. Фрязино : Век 2, 2011. 320 с.

Прибрам К. Языки мозга: Экспериментальные парадоксы и принципы нейропсихологии. Москва : Прогресс, 1975. 301 с.

Роменец В. А. Ж Кизнь и смерть: Постижение разумом и верой. Киев : Лыбидь, 2003. 230 с.

Соколов Е. Н. Векторная психофизиология. Санкт-Петербург : Питер, 2006. C. 458-455.

Фурман А. В. Свідомість як передумова психологічного пізнання і професійного методологування. Наука і освіта. 2017. № 3. С. 5-10.

Хант Г. О природе сознания. С когнитивной, феноменологической и трансперсональной точек зрения. Москва : АCТ, Институт трансперсональной психологии, 2004. 555 с.

Шанже З̊.-П. Нейрофизиологические основы этического поведения. Человек. № 5. 1999. С 54-84.

Швырков В. Б. Введение в объективную психологию. Нейрональные основы психики. Москва : Институт психологии РАН, 2006. 592 с.

Эдельман Дж. Разумный мозг. Москва : Наука, 1981. 165 с.

Almaas, A. H. (1996). Essence - the diamond approach to inner realization. York Beach : Samuel Weiser. 67 p.

Everett, Hugh (2007). Relative State Formulation of Quantum Mechanics. Reviews of Modern Physics. Cambridge University Press. $214 \mathrm{p}$.

Kalishchuk, S. (2018). Construction of ontological models of consciousness of personality. PNAP Sientific Journal of Polonia, 1 (26), 95-100, Czestochowa.

Varela, F. (1995). Resonant Cell Fssemblies. Biological Research, 5 (24), 81-95.

\section{References}

Beskova, I. A. (2001). Evoljutsija i soznanie: kognitivno-simvolicheskij analiz [Evolution and Consciousness: cognitive-symbolic analysis]. Moskva : IF RAN [in Russian].

Bom, D. (1967). Spetsial'naja teorija otnositel'nosti [Special theory of relativity]. Moskva : Mir [in Russian]. 
Vekker, L. M.(1998). Psihika i real'nost': Jedinaja teorija psihicheskih protsessov [Psyche and Reality: A Unified Theory of Mental Processes ]. Moskva : Smysl [in Russian].

Gejzenberg, V. (2015). Printsip neopredelennosti [Uncertainty principle]. Moskva : De Agostini [in Russian].

Gibson, D. (1988). Ekologicheskij podhod k zritel'nomu vosprijatiju [Ecological approach to visual perception]. Moskva : Progress [in Russian].

Danilova, N. N. (1999). Psihofiziologija [Psychophysiology]. Moskva : Aspekt Press [in Russian].

Ivanytskyi, O. M. (2005). Svidomist i mozok [Consciousness and the brain]. U sviti nauki - In the world of science, 11, 9-14 [in Ukrainian].

Ivanov, A. V. (2008). Mir soznanija [World of consciousness]. Barnaul : Altajskij dom pechati [in Russian].

Kapra, F. (2002). Pautina zhizni [Web of life]. Sofija : Gelios [in Russian].

Menskij, M. B. (2011). Soznanie $i$ kvantovaja mehanika: Zhizn' $v$ parallel'nyh mirah [Consciousness and Quantum Mechanics: Life in Parallel Worlds ]. Frjazino : Vek 2 [in Russian].

Pribram, K. (1975). Jazyki mozga: Jeksperimental'nye paradoksy $i$ printsipy nejropsihologii [Languages of the brain: Experimental paradoxes and principles of neuropsychology]. Moskva : Progress [in Russian].

Romenets, V. A. (2003). Zhizn' i smert': Postizhenie razumom i veroj [Life and death: Comprehension through reason and faith]. Kiev: Lybid', 2003 [in Russian].

Sokolov, E. N. (2006). Vektornaja psihofiziologija [Vector psychophysiology]. Sankt-Peterburg : Piter [in Russian].

Furman, A. V. (2017). Svidomist yak peredumova psykholohichnoho piznannia i profesiinoho metodolohuvannia [Consciousness as a prerequisite for psychological knowledge and professional methodology]. Nauka i osvita - Science and education, 3, 5-10 [in Ukrainian].

Hant, G. (2004). O prirode soznanija. S kognitivnoj, fenomenologicheskoj $i$ transpersonal'noj tochek zrenija [About the nature of consciousness. From cognitive, phenomenological and transpersonal points of view]. Moskva : AST, Institut transpersonal'noj psihologii [in Russian].

Shanzhe, Zh.-P. (1999). Nejrofiziologicheskie osnovy jeticheskogo povedenija [Neurophysiological bases of ethical behavior]. Chelovek - Human, 5, 54-84 [in Russian].

Shvyrkov, V. B. (2006). Vvedenie v ob'ektivnuju psihologiju. Nejronaljnye osnovy psihiki [Introduction to objective psychology. Neural fundamentals of the psyche]. Moskva : Institut psihologii RAN [in Russian].

Jedel'man, D. (1981). Razumnyj mozg [Reasonable brain]. Moskva : Nauka [in Russian]. 
Almaas, A. H. (1996). Essence - the diamond approach to inner realization. York Beach : Samuel Weiser.

Everett, Hugh (2007). Relative State Formulation of Quantum Mechanics. Reviews of Modern Physics. Cambridge University Press.

Kalishchuk, S. (2018). Construction of ontological models of consciousness of personality. PNAP Sientific Journal of Polonia, 1 (26), 95-100, Czestochowa.

Varela, F. (1995). Resonant Cell Fssemblies. Biological Research, 5 (24), 81-95.

Калішук Світлана. Об'єктивний підхід до трактування свідомості: нейрофізіологічний, фізичний і математичний дискурси

\section{АНОТАЦІЯ}

У статmі описано базові дослідження об'єктивного пізнання свідомосmi, що розкривають різні аспекти формування досвіду розрізнення та випромінювання свідомості. Проаналізовано взаємодоповнюючі підходи природничо-наукового дискурсу дослідження свідомості, а саме: нейрофізіологічний, який порушує питання про біологічні засади міжрівневого феномену свідомості та визначає фізіологічні основи структурно-функціональної будови свідомості; квантово-механічний, що спирається на практику експериментального дослідження квантової реальності та пояснює феномен "свідомості»; загально-системний, який цілісно і логіко-концептуально дозволяє змоделювати системний простір свідомості та виступає операційною парадигмою ї̈ дослідження. Методами моделювання та реконструкції досліджено склад змістовних і структурних внутрішніх, формально-логічних і функціональних ознак свідомості та відтворено ії сутнісні ознаки. Розкрито сутність впливових класичних і сучасних нейрофізіологічних теорій свідомості. Нейропсихологічні теорії можна розглядати як структурно-функціональну парадигму, що характеризує функції та рамки специфічних нейронних мереж як прояв конкретного когнітивного прочесу, синхронізації різноманітних нейронних ланцюгів і залучення нових нейронних шляхів на тлі збереження функції старих, згортання й розгортання множинних фрорм інформації та як прояв злиття досвіду пережитого цілого. Положення квантової механіки виступають як пояснювальна парадигма, в рамках якої пояснюється феномен змінених станів свідомості та змістова будова свідомості, одиницями якої виступають смисли. Загальна теорія систем забезпечує: побудову системної «семантичної території» свідомості особистості; знаходжен- 
ня точок біфуркації, у яких проявлено максимально повний набір потенційних можливостей зростання системи; визначення підсилюючого та врівноважуючого контурів зворотного зв'язку; бажаного стану системи; виду атракторів; потенціалу самопрояву і самозвільнення у персональній активності та побудові щоразу унікальної власної реальності шляхом безперервного обміну із зовнішнім світом.

Ключові слова: свідомість, нейрофізіологія свідомості, квантова механіка, загальна теорія систем, структурно-функціональна парадигма, пояснювальна парадигма, операційна парадигма.

Калищук Светлана. Объективный подход к трактовке сознания: нейрофизиологчческий, физический и математический дискурсы

\section{АННОТАЦИЯ}

В статье описаны базовые исследования объективного познания сознания, раскрывающие различные аспекты формирования навыка различения и излучения сознания. Проанализированы взаимодополняющие подходы естественно-научного дискурса исследования сознания, а именно: нейрофизиологические, которые ставят вопрос о биологических основах межуровневого феномена сознания и определяют физиологические основы структурно-функционального строения сознания; квантово-механический, опирающийся на практику экспериментального исследования квантовой реальности и объясняющий феномен "сознания», и общесистемный, который целостно и логико-концептуально позволяет смоделировать системное пространство сознания и выступает операционной парадигмой его исследования. Методами теоретического моделирования и реконструкции исследованы содержательные и структурные формально-логчческие и функциональные признаки сознания. Раскрыта сущность классических и современных нейрофизиологических теорий сознания. Нейропсихологические теории можно рассматривать в качестве структурно-функциональной парадигмы, исследующей функции специфических нейронных сетей, когнитивных процессов, синхронизации нейронных цепей и создания новых нейронных путей на фоне сохранения функции старых, свертывания и развертывания множественных форм информации, слияния опыта пережитого челого. Положения квантовой механики выступают в качестве объяснительной парадигмы, в рамках которой истолковывается феномен измененных состояний сознания и содержательное строение сознания, единицами которого выступают смыслы, стремящиеся со- 
отнести осознанное качество с интегральной картиной мира благодаря существованию смыслового поля. Общая теория систем обеспечивает: построение системной "семантической территории» сознания личности; нахождение точек бифуркации, в которых проявлен максимально полный набор потенциальных возможностей роста системы; определение усиливающего и уравновешивающего контуров обратной связи; желаемого состояния системы; вида аттракторов; потенциала самопроявления и самоосвобождения в персональной активности и построении уникальной собственной реальности через непрерывный обмен с внешним миром.

Ключевые слова: сознание, нейрофизиология сознания, квантовая механика, общая теория систем, структурно-функциональная парадигма, объяснительная парадигма, операционная парадигма. 